\title{
Relationship between Surging Phenomenon and Processing Conditions in False Twisting
}

\author{
KANEDA Naoto $^{\text {a }}{ }^{*}$, HAYASHIDA Kouichi ${ }^{\text {a }}$, KinARI Toshiyasu ${ }^{\mathrm{b}}$ \\ ${ }^{a}$ National Institute of Technology, Fukui College, Geshi-Cho, Sabae, Fukui 916-8507, Japan \\ ${ }^{\mathrm{b}}$ Kanazawa University, Kakuma-Machi, Kanazawa, Ishikawa 920-1192, Japan
}

Received 3 September 2020; accepted for publication 18 March 2021

\begin{abstract}
Surging in the false-twisting machine degrades yarn quality. Surging is a yarn vibration phenomenon, and its cause has not been clarified. It is an important issue to clarify the causes of surging from the viewpoint of the textile industry. Investigating the causes of surging contributes to not only higher processing speed but also higher processing efficiency. This investigation also contributes to stabilizing the yarn quality at the false-twisting production site. In this study, a disc-friction type model machine was used to evaluate the yarn conditions of false twisting with and without surging. It was observed that surging tends to occur at low drawing ratios and high-speed processing. In the addon twisting area, the number of twists, drawing quantity, yarn tension, yarn temperature, and heating time decreased because of the occurrence of surging. These results show the actual condition of the yarns with surging and confirm the interrelationship between surging and processing conditions of false twisting.
\end{abstract}

Key Words : Surging, False twist, Disc friction, Yarn shape

\author{
仮撚加工におけるサージング現象と加工条件の関係 \\ 金田直人 ${ }^{\mathrm{a}, *}$ ，林田剛一 ${ }^{\mathrm{a}}$, 喜成年泰 ${ }^{\mathrm{b}}$ \\ ${ }^{a}$ 福井工業高等専門学校, ${ }^{b}$ 金沢大学
}

\section{1. 緒 言}

仮撚加工法は, 糸に加撚と解然を付与する施撚体としてピ ンタイプ・ベルトニップタイプ・ディスクフリクションタイ プ等が確立されており，これらを設置した仮撚加工機の加工 条件を変更することで様々な加工糸を生産している．生産現 場においては, 多品種小ロットから大量生産までと市場のあ らゆるニーズに対応可能な仮撚加工機が求められている。 そ のため, 仮撚加工機は市場からのニーズに応えるべく高性能 化が進められており, 近年ではヒー夕・冷却装置・施撚体の 開発およびコンピュータの発展によって, 高生産性, 品質安 定化, 省人化が実現している [1-2]. このように設備仕様上 における高性能化は進められているが, 実際の仮撚加工機の 加工速度の高速化に関しては頭打ちとなっているのが現状で ある。これは加工の高速化に伴い，加工中の糸が不安定に張
力変動する振動現象（以下, サージングと称す）の発生が原 因となっている [3]. そのため, サージングは糸切れや未解 撚等を誘発し加工糸の糸品質を著しく低下させる。仮撚加工 法に関しては, 加熱部・冷却部・施撚部の加工メカニズムに ついて数多く報告 [4-9]さされており, また, 著者らもディス クフリクションタイプの施撚部における糸径路および糸張 力の数学モデルの構築ならびに同部の糸形状を実験的に検証 し, ディスクが糸に付与する加然と解撚について研究 [10-12] しているものの, いずれもサージング未発生の場合に留まっ ている。サージングは糸に撚りを与える施撚体の表面やヒー 夕内の発熱面の状態にも影響を受ける [3] といわれている が，サージング発生時の糸の実態についてはほとんど公表が なく, 仮撚加工法が系に延伸 · 加熱 - 加撚 - 冷却 · 解撚を連 続的に付与する複雑な高次加工であることから発生要因も断 定できていないため，具体的な抑制方法については未だ報告

* 連絡先 : 福井工業高等専門学校機械工学科 916-8507 福井県鯖江市下司町

E-mail : kaneda@fukui-nct.ac.jp, Tel : +81-778-62-8251, Fax : +81-778-62-8251 
されていない。したがって、サージング発生有無による糸の 状態と加工条件との関係を把握することは, サージングの発 生要因ならびに抑制方法を検討するための基礎資料となり， 今後の仮撚加工機の開発において加工速度の高速化のみなら ず加工効率の向上, さらには生産現場における品質安定化に も寄与するといえるため産業的にも有用といえる.

そこで本報では, 仮撚加工機におけるサージングと加工条 件との相互関係を明確にすることを目的とし，ディスクフリ クションタイプのモデル機を用いて, 加工糸を生産する上で 重要とされている加工条件の 4T (張力・撚り・加熱温度 加熱時間）の観点 [13] から, サージングの未発生時と発生 時での実態を把握した。ここでは, 糸張力および糸形状, 糸 温度, 糸速度を測定対象に, 主に加撚領域での相互関係につ いて比較・検証した。

\section{2. 実験装置の基本構成}

実験に用いたディスクフリクションタイプのモデル機を Fig. 1 に示す。本機は糸送り・延伸用のフィードローラ（周 速度 $\left.V_{f}\right)$ およびデリベリローラ（周速度 $V_{d}$ ), 熱固定用のヒー 夕 (ヒー夕温度 $T_{H}$ ), 冷却用の冷却装置, また施然体は複数 枚のディスク（周速度 $D$ ） から成る三軸型のディスクユニッ トとして施撚部に設置している。原糸は，フィードローラと デリベリローラによって把持され，各ローラの速度差によっ て延伸（延伸比 $V_{d} / V_{f}$ ) されながらデリベリローラ側に向かっ て走行している，また，下流に設置している施撚体と糸との 摩擦により糸が加撚され, 走行中にヒータと冷却装置によっ て熱固定される。そして, 加撚・熱固定後の糸が施撚部を通 過後に解撚し, 原糸には加撚 - 延伸 - 加熱 - 冷却 - 解撚の順 で連続的に加工が付与され加工糸が生産される。実験装置に はサージング未発生時と発生時での加工中の糸の様子を把握 するために, 糸形状および糸温度を測定するヒータ入口から 施撚部まで糸進行方向に移動可能な高速度カメラ (FASTCAM Mini AX100: (株) Photron) と熱画像カメラ (CPA-T540S: (株) チノー）を設置した。ささに，ヒータ入口前・ヒータ出口後・ 冷却装置後・施撚部前・施撚部後の 5 箇所 (同図 $\odot: 1 \sim 5$ ) には, 張力計（ETPX-500：SCHMIDT）を設置した. ここで

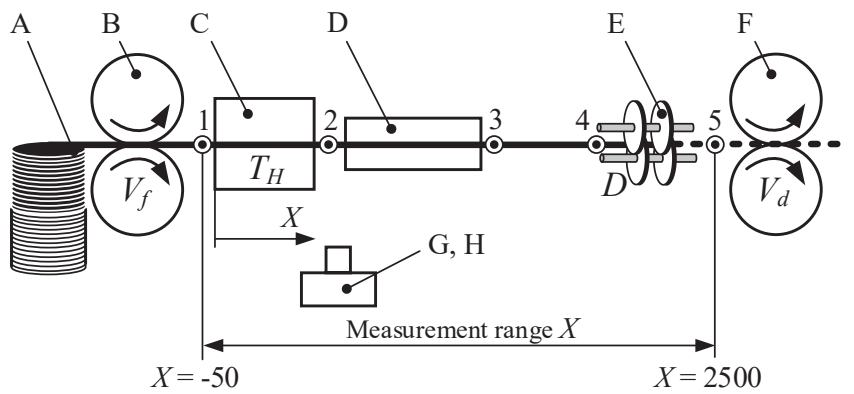
A : Original yarn (POY:Black and White)
E : Disc
B : Feed roller
$\mathrm{F}:$ Delivery roller
C : Heater
G : High-speed camera
$\mathrm{D}$ : Cooling equipment
$\mathrm{H}$ : Thermo camera

Fig. 1 Outline of model disc friction false twister.
測定した糸張力については, 以下, ヒータ入口前から順に $T_{1}, T_{2}, \cdot \cdots T_{5}$ と称す。また, サージングの発生有無によっ て加工中の糸速度も変化すると予想されるため, 糸張力と同 じ 5 箇所に, Fig. 2 に示すような走行中の糸と接触する回転 ローラを設置した。 なお, 糸張力と糸速度は, 1 ～０順に 測定機器を系軸方向に移動して測定を行った。

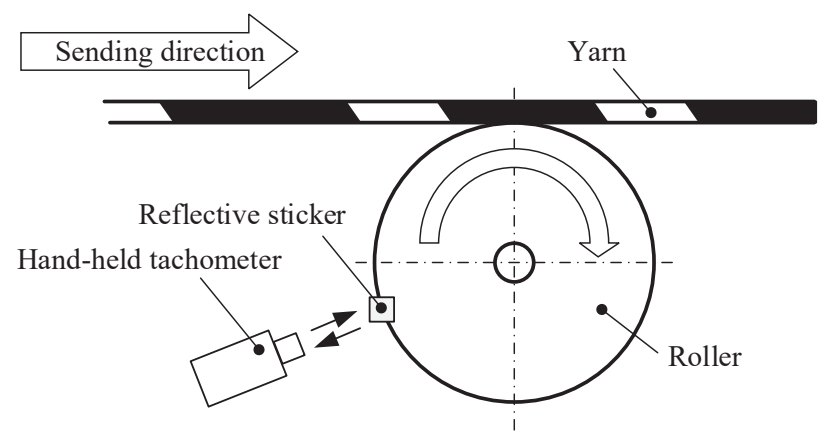

Fig. 2 Measurement of yarn velocity with contact-type rotating disc.

\section{3. 実験方法}

本研究ではフィードローラから施撚部までを加撚領域と定 義し, 同領域における糸張力, 糸形状, 糸温度, 糸速度を測 定対象にサージング未発生時と発生時での比較・検証を行っ た。また，糸形状を表現するパラメータとして，Fig. 3 に示 す見かけ糸太さ $d$ と撚角度 $\theta$ を採用した [11]. この糸形状 $d$, $\theta$ は加撚領域での加工中の糸を高速度カメラで撮影した後, 動画解析ソフト (Photron FASTCAM Viewer：(株) Photron) を用いて測定した。糸温度 $T_{y}$ も同様に, 同領域での糸を熱 画像カメラで撮影した後, 熱解析ソフト (FLIR Tools : FLIR ${ }^{\circledR}$ Systems, Inc.）を用いて測定した。糸形状 $d, \theta$ および糸温度 $T_{y}$ の測定は, Fig. 1 に示すように加撚領域内でのヒータ入口 を原点 $(X=0 \mathrm{~mm})$ として, 前者はヒータ入口前からヒータ 出口の $X=-50 \sim 1000 \mathrm{~mm}$ までを, 後者はヒータ入口前から 冷却装置後の $X=-50 \sim 1650 \mathrm{~mm}$ で行った. また, 糸張力 $T$ は張力計より施撚部前後の加撚張力 $\left(T_{1} \sim T_{4}\right)$ および解撚張 力 $\left(T_{5}\right)$ [13] を電圧信号としてメモリハイコーダ（MR8880： 日置電機 (株) ) にて測定し, 糸速度 $V_{y}$ は Fig. 2 に示す回転ロー ラに反射シールを添付することで, 回転速度を検出するハン ディタコメータ (HT-4200：小野測器（株））の測定值を基に 算出した。 なお, 実験での原糸は加工中の糸形状を観察し易 くするために, 黒色と白色の 2 種類の POY（ポリエステル マルチフィラメント）を用いて, フィードローラで取り込む 時に双系状態となるよう糸送りした。

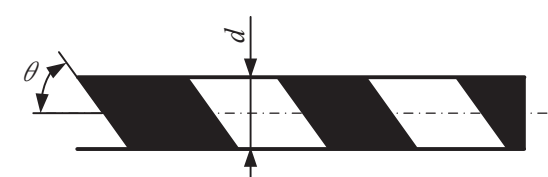

Fig. 3 Apparent yarn thickness $d$ and angle of twist $\theta$. 
Table 1 Experimental conditions.

\begin{tabular}{lcc|c}
\hline $\begin{array}{l}\text { Original yarn } \\
\text { (PET - POY) }\end{array}$ & & \multirow{2}{*}{ dtex / $\mathrm{f}$} & Black yarn $133 / 36$ \\
\cline { 4 - 4 } & & & White yarn $133 / 36$ \\
\hline Heater temperature & $T_{H}$ & ${ }^{\circ} \mathrm{C}$ & $250,300,350$ \\
\hline Delivery velocity & $V_{d}$ & $\mathrm{~m} / \mathrm{min}$ & $300,500,800$ \\
\hline Draw ratio & $V_{d} / V_{f}$ & & $\begin{array}{c}1.10-2.00 \\
\text { in } 0.05 \text { increments }\end{array}$ \\
\hline Speed ratio & $D / V_{d}$ & & 1.60 \\
\hline
\end{tabular}

Table 1 に実験条件を示す。本実験では加工糸の糸品質に影 響を及ぼす条件であるヒー夕温度 $T_{H}$, 糸送り速度 $V_{d}$, 延伸 比 $V_{d} / V_{f}$, 速度比 $D / V_{d}$ をパラメータに加工を行った. ここ で，まず速度比 $D / V_{d}$ を一定とした場合におけるヒー夕温度 $T_{H}$ および糸送り速度 $V_{d}$, 延伸比 $V_{d} / V_{f}$ を変化させていき, サー ジングが発生しやすい加工条件を把握した。

\section{4. 実験結果および考察}

Fig. 4 にヒータ温度 $T_{H}=250{ }^{\circ} \mathrm{C}$, 糸送り速度 $V_{d}=500 \mathrm{~m} / \mathrm{min}$ でのヒー夕内および施然体（ディスク）上における加工中の 糸の様子を示す。同図は高速度カメラの撮影速度 $1 / 20000 \mathrm{~s}$ に よる画像で, (a) は延伸比 $V_{d} / V_{f}=1.70$ でのサージング未発 生を，（b）は延伸比 $V_{d} / V_{f}=1.40$ でのサージング発生を示し ている。これよりサージング発生時では, 糸の振動が加工機 全体で生じていることが確認できる。特に同図（b）での施
撚体上における糸の振動は, 糸とディスクの接触状態が悪化 しているといえ, 加撚・解撚・糸送り作用といった加工効率 を著しく低下させていると想定できる.ここで Fig. 5 に示す 通り，糸送り作用は糸とディスクが接触することで発生する 糸進行と同じ方向の $D \sin \varphi$ のことであり，ディスク回転速度 $D$ と糸とディスクのなす角である糸傾角 $\varphi$ に依存する [4-12].



Fig. 5 Yarn sending effect on the friction disc [5].

Table 2 - Table 3 に速度比 $D / V_{d}=1.60$ におけるヒー夕温度 $T_{H}$ が $250{ }^{\circ} \mathrm{C}, 350{ }^{\circ} \mathrm{C}$ の場合での, サージングの発生状況を目 視と張力変動で確認した結果を示す。同表は延伸比 $V_{d} / V_{f}$ お よび糸送り速度 $V_{d}$ をパラメータとしており，○はサージン グが未発生状態，×はサージングが発生状態である（以下， サージング未発生を○, サージング発生を×で示す)。これ らの結果より, サージングは糸送り速度 $V_{d}$ が速く, 延伸比
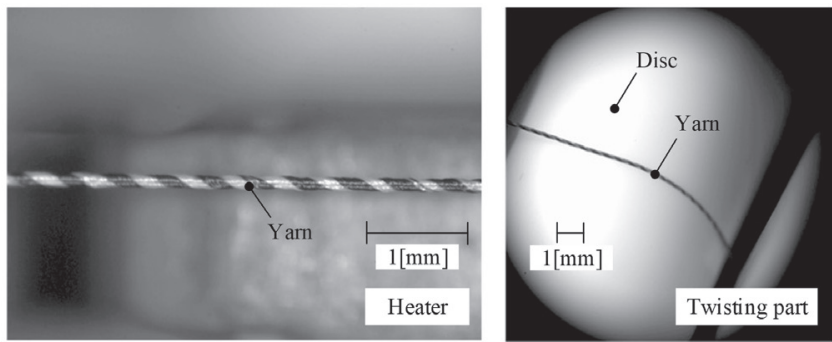

(a) Yarn without surging
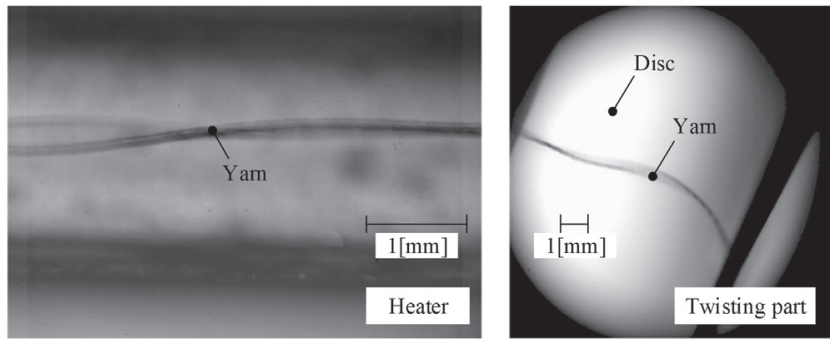

(b) Yarn with surging

Fig. 4 Differences by surging.

Table 2 Occurrence status of surging at $T_{H}=250^{\circ} \mathrm{C}$. ( $\bigcirc$ : without surging, $\quad \times$ : with surging)

\begin{tabular}{|c|c|c|c|c|c|c|c|c|c|c|c|}
\hline \multirow{2}{*}{\multicolumn{2}{|c|}{$T_{H}=250^{\circ} \mathrm{C}$}} & \multicolumn{10}{|c|}{ Draw ratio $V_{d} / V_{f}$} \\
\hline & & 1.10 & 1.20 & 1.30 & 1.40 & 1.50 & 1.60 & 1.70 & 1.80 & 1.90 & 2.00 \\
\hline \multirow{3}{*}{$\begin{array}{c}V_{d} \\
\mathrm{~m} / \mathrm{min}\end{array}$} & 300 & $x$ & $x$ & 0 & 0 & 0 & 0 & 0 & 0 & 0 & 0 \\
\hline & 500 & $x$ & $x$ & $x$ & $x$ & $x$ & $\bigcirc$ & $\bigcirc$ &  & $\bigcirc$ & $\mathrm{O}$ \\
\hline & 800 & $x$ & $x$ & $x$ & $x$ & $x$ & $x$ & $x$ & 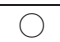 & O & 0 \\
\hline
\end{tabular}

Table 3 Occurrence status of surging at $T_{H}=350{ }^{\circ} \mathrm{C}$. ( $\bigcirc$ : without surging, $\quad \times$ : with surging)

\begin{tabular}{|c|c|c|c|c|c|c|c|c|c|c|c|}
\hline \multirow{2}{*}{\multicolumn{2}{|c|}{$T_{H}=350{ }^{\circ} \mathrm{C}$}} & \multicolumn{10}{|c|}{ Draw ratio $V_{d} / V_{f}$} \\
\hline & & 1.10 & 1.20 & 1.30 & 1.40 & 1.50 & 1.60 & 1.70 & 1.80 & 1.90 & 2.00 \\
\hline \multirow{3}{*}{$\begin{array}{c}V_{d} \\
\mathrm{~m} / \mathrm{min}\end{array}$} & 300 & $x$ & $x$ & 0 & 0 & 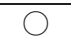 & 0 & 0 & 0 & 0 & O \\
\hline & 500 & $x$ & $x$ & $x$ & $x$ & 0 & $\mathrm{O}$ & $\mathrm{O}$ & $\bigcirc$ & 0 & 0 \\
\hline & 800 & $x$ & $x$ & $x$ & $x$ & $x$ & $x$ & $x$ & 0 & 0 & 0 \\
\hline
\end{tabular}


$V_{d} / V_{f}$ が低いほど発生しやすくなることが確認できる。ここ でヒー夕温度 $T_{H}$ に着目すると, 同温度が $100{ }^{\circ} \mathrm{C}$ 増加した場合, 糸送り速度 $V_{d}=500 \mathrm{~m} / \mathrm{min}$ 抢よび延伸比 $V_{d} / V_{f}=1.50$ におい て, サージングの発生が未発生となり一部抑制がみられるが, 全体的な発生状況には大きな差異がなかった。したがって， ヒー夕温度 $T_{H}$ はサージングの抑制にあまり影響を及ぼさな いといえる。上記をふまえて，測定結果に対する考察を以下 に示す.

\section{1 糸張力への影響}

Fig. 6 にヒー夕温度 $T_{H}=300{ }^{\circ} \mathrm{C}$, 糸送り速度 $V_{d}=500 \mathrm{~m} / \mathrm{min}$ における延伸比 $V_{d} / V_{f}=1.40$ のサージング発生, 同 $V_{d} / V_{f}=1.60$ のサージング未発生での加工機全体の時間的平均張力 $T$ を示 す。同図より, サージング発生と未発生とを比較すると, 糸 張力 $T$ は $T_{1}$ から $T_{4}$ までサージング未発生の方が約 $20 \mathrm{cN}$ 程 大きかった。これは延伸比 $V_{d} / V_{f}$ の違いが一因といえる.また， サージング発生の有無に関わらず，両者とも $T_{1}$ から $T_{4}$ まで 増加傾向にあるが, 施撚部通過後ではサージング発生の解撚 張力 $T_{5}$ がサージング未発生よりも大きくなっていた。これ よりサージングの発生は，特に施然部前後の糸張力 $T$ に大き く影響を及ぼすことが確認できる。ここで同部前後の加撚張 力 $T_{4}$ と解撚張力 $T_{5}$ に着目する. Fig. 7 に同 $T_{H}=300{ }^{\circ} \mathrm{C}, V_{d}=$ $500 \mathrm{~m} / \mathrm{min}$ での延伸比 $V_{d} / V_{f}$ ごとの (a) 加撚張力 $T_{4}$ および 解撚張力 $T_{5}$ と (b) 変動係数 $C V$ を示す。同図 (a) より, 1.50 $\leqq V_{d} / V_{f} \leqq 1.80$ でのサージング未発生時では，施撚部の糸と ディスク間の接触状態が良好のため Fig. 5 の糸送り作用が発 揮されていることから $T_{4}>T_{5}$ の関係となっており，系切れ が生じ難い加工状態であるといえる。一方， $V_{d} / V_{f}=1.50$ 未 満ではサージングの発生によって接触状態が悪化するため, 糸送り作用が発揮されにくく $T_{4}<T_{5}$ の関係になっているこ とが確認できる。これより，サージング発生時では施撚部で の糸送り作用が糸張力に大きく影響を及ぼすといえる。ま た, サージングが発生している $T_{4}<T_{5}$ の関係は, 延伸比 $V_{d} /$ $V_{f}$ の低下に伴い差異が小さくなっていった。この原因として は，ディスクが糸に付与していた摩擦力による加然作用およ

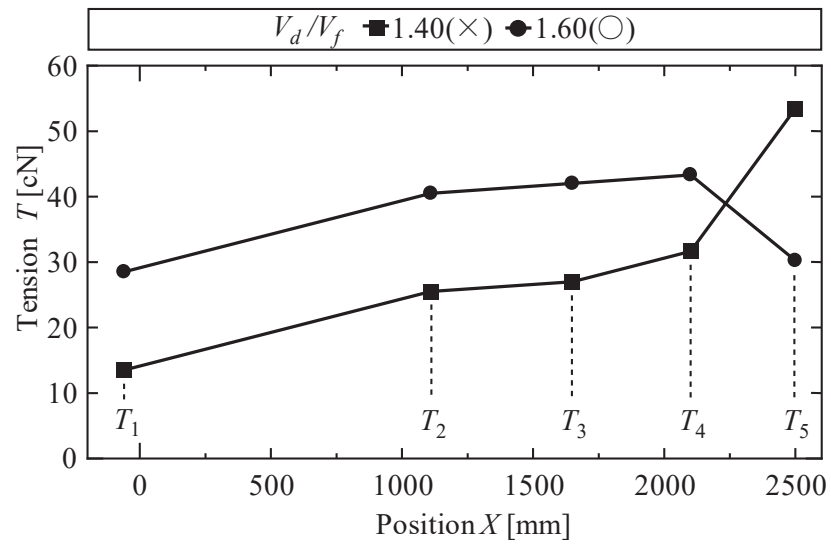

Fig. 6 Tension $T$ from feed roller to front of disc. $(\bigcirc$ : without surging, $\quad \times$ : with surging

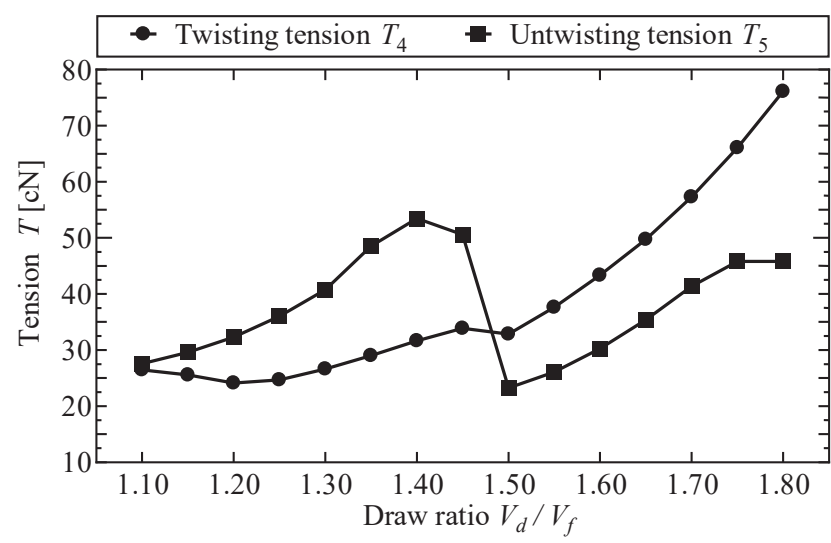

(a) Tension $T$ of twisting and untwisting tension



(b) Coefficient of variation $C V$ of twisting and untwisting tension

Fig. 7 Measurement results of yarn tension at $T_{H}=300{ }^{\circ} \mathrm{C}$.

び糸送り作用が発揮されなくなったことが考えられる。この 摩擦力は, 加工中の糸がディスクに接触することで生じる糸 張力のディスク中心方向への分力（以下，把持力と称す）に 起因するといえる. Fig. 8 に同 $T_{H}=300{ }^{\circ} \mathrm{C}, V_{d}=500 \mathrm{~m} / \mathrm{min}$ で の延伸比 $V_{d} / V_{f}=1.35,1.45,1.60$ における加工中の解撚張 力 $T_{5}$ の結果を示す. 同図より, サージング未発生から発生 に切り替わる延伸比 $V_{d} / V_{f}=1.45$ において張力変動が最も大 きくなっており, 延伸比 $V_{d} / V_{f}$ が低下すると張力変動も小さ

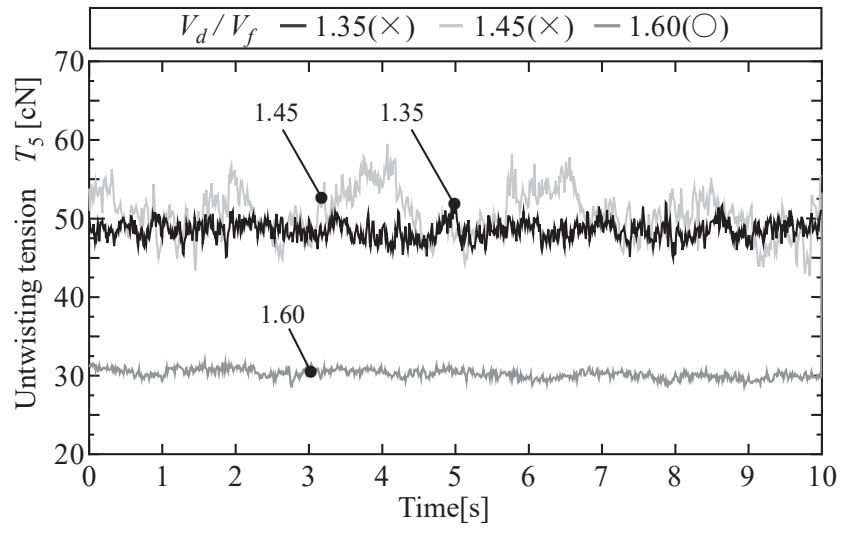

Fig. 8 Untwisting tension at $T_{H}=300{ }^{\circ} \mathrm{C}$. ( $\bigcirc$ : without surging, $\quad \times$ : with surging) 
くなっていった.これはFig. 7(b) からも確認することができ， サージングが発生する $V_{d} / V_{f}=1.45$ で変動係数 $C V$ が約 $6 \%$ を 示しており, $V_{d} / V_{f}=1.45$ 未満では $1 \sim 3 \%$ 程度に収まって いった，両図より，サージングについて低周期で大きな張力 変動 $\left(V_{d} / V_{f}=1.45\right)$ するものと, 高周期で小さな張力変動 $\left(V_{d}\right.$ $\left./ V_{f}=1.35\right)$ するものとの 2 種類あることを確認することがで きた。 なお， $V_{d} / V_{f}=1.45$ での張力変動が急激に大きくなる のは，糸をディスク上に留めようとする把持力とディスクが 回転力によって糸を弾き出そうとする力のつりあいがとれな くなった作用反作用が最も強く発生している状況と考えられ る.ここで, Fig. 7 (b) の $1.50 \leqq V_{d} / V_{f} \leqq 1.80$ と 1.45 未満 では変動係数 $C V$ が一見すると同程度を示しているが, サー ジングが生じている Fig. 8 の 1.45 未満では解撚張力 $T_{5}$ が未 発生時と比べて $20 \mathrm{cN}$ 程大きくなっていることから, 施撚部 での糸送り作用が発揮されていないといえる。したがって， 変動係数 $C V$ のみではサージングの発生有無の判断が困難と いえ，施撚部前後での糸張力の関係も含めていく必要がある と考えられる。前述した通り, 延伸比 $V_{d} / V_{f}$ の低下は加工中 の糸の把持力の低下にもつながることから, サージングの発 生には糸張力の低下が起因していると考えられるが, 現段階 ではサージングの発生要因として断定に至っていない.

\section{2 糸形状への影響}

Fig. 9 に加熱温度 $T_{H}=300{ }^{\circ} \mathrm{C}$, 糸送り速度 $V_{d}=500 \mathrm{~m} / \mathrm{min}$ の場合でのヒータ内に拈ける糸形状 $d, \theta$ を示す。ここでサー
ジング発生の延伸比 $V_{d} / V_{f}=1.40$ か $\square$ ○゙，未発生の $V_{d} / V_{f}$ $=1.60$ が○・坖る. 同図より, ヒー夕長 $1000 \mathrm{~mm}$ のヒー 夕内に拈い, サージング未発生時では $X=300 \sim 500 \mathrm{~mm}$ 付近で見かけ糸太さ $d$ が減少し, 撚角度 $\theta$ が増加しており, 発生時では $X=700 \sim 800 \mathrm{~mm}$ 付近で同現象が確認できた. これよりサージング未発生時と発生時とでは, ヒー夕内で の糸形状が変化するまでの時間が異なることが明らかとなっ た。つまり, サージングが発生するとヒー夕内で加撚されに くくなるといえる。また, サージング発生時は糸がヒータ内 を進行するにつれ撚角度 $\theta$ が増加しているものの未発生時に 比べ約 $10 \sim 20 \mathrm{deg}$. 程全体的に低下していた。この結果から も明らかなように, サージング発生時は施撚部からの加然作 用が低下しているといえる。前述した通り, サージングは加 工中の糸の不安定に挙動する振動現象であり, この振動現象 はフィードローラからデリベリローラまでの全領域で生じて いる。したがって, 糸とディスクの接触も不安定となり摩擦 力の低下, すなわち加然が十分に付与されないためサージン グ発生時では撚角度 $\theta$ が低くなったと考えられる。ここで一 般的に加撚状態の系を系軸方向へ延伸すると, 見かけ系太さ $d$ と撚角度 $\theta$ が減少するが, 本結果では延伸比 $V_{d} / V_{f}$ によっ て延伸を糸に付与しているにも関わらず，見かけ糸太さ $d$ は $0.14 \mathrm{~mm}$ に低下したまま, 撚角度 $\theta$ は $45 \mathrm{deg}$. に増加した後 に一定の值を維持していた。つまり, 加工中の糸に加撚作用 が働けば，撚りトルクによってフィラメントが Fig. 10 に示 すように螺旋方向に延伸 [14]され, 撚角度 $\theta$ が減少せずに 総合的に見かけ糸太さ $d$ のみが減少したと考えられる。また，



Fig. 9 Yarn shape in heater at $T_{H}=300{ }^{\circ} \mathrm{C}$. ( $\bigcirc$ : without surging, $\quad X$ : with surging)

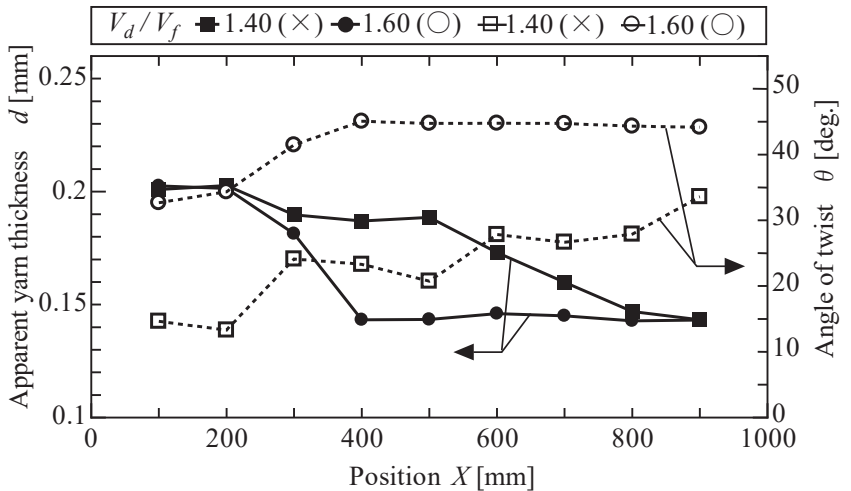

Fig. 11 Yarn shape in heater at $T_{H}=350^{\circ} \mathrm{C}$. ( $\bigcirc$ : without surging, $\quad \times$ : with surging)
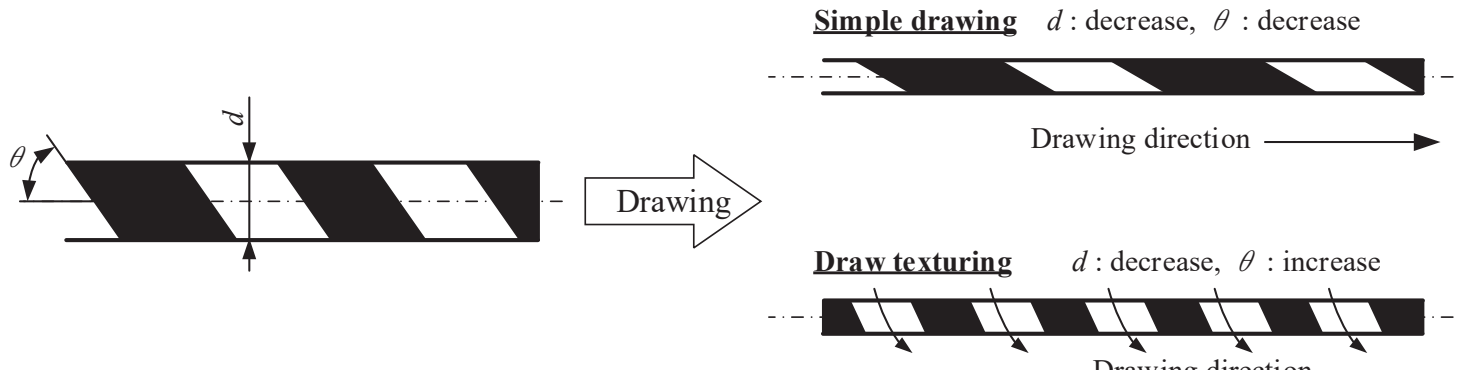

Fig. 10 Drawing direction with twisting. 
加工中の糸は加撚によって糸軸方向に収縮作用も発生するた め, ヒー夕内の糸は糸軸方向に収縮しながら螺旋方向に延伸 しているといえる. Fig. 11 にヒー夕温度 $T_{H}=350{ }^{\circ} \mathrm{C}$, 系送り 速度 $V_{d}=500 \mathrm{~m} / \mathrm{min}$ の場合でのヒータ内における糸形状 $d, \theta$ を示す。ここでサージング発生の延伸比 $V_{d} / V_{f}=1.40$ か

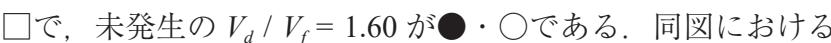
サージング未発生時に着目すると, 糸は $X=200 \sim 400 \mathrm{~mm}$ 付 近で延伸されており，Fig. 9 の未発生時と比べて糸の延伸が 早くなっていることがわかる。このように延伸されるのは原 糸が有するガラス転移温度 (ポリエステルの場合, 約 $80{ }^{\circ} \mathrm{C}$ ) が影響しているといえ, Fig. 11 は Fig. 9 よりヒー夕温度 $T_{H}$ が $50{ }^{\circ} \mathrm{C}$ 高いことから，加工中の糸がガラス転移温度に早く 達し，延伸が早くなったと考えられる [15-16].

\section{3 糸温度および系速度への影響}

Fig. 12 にヒー夕温度 $T_{H}=300^{\circ} \mathrm{C}$, 糸送り速度 $V_{d}=500 \mathrm{~m} / \mathrm{min}$ の場合における $V_{d} / V_{f}=1.40,1.60$ での糸温度 $T_{y}$ の測定結果 を示す。ここでサージング発生がロで，未発生が○である。 同図より, 糸温度 $T_{y}$ はサージングの発生の有無に関わらず $X$ $=400 \mathrm{~mm}$ から上昇しはじめており， $X=800 \mathrm{~mm}$ において収 束していることが確認できる。本結果を前述したガラス転移 温度 (約 $80{ }^{\circ} \mathrm{C}$ ) の観点で注目すると, 糸の変形が生じる前 から $100{ }^{\circ} \mathrm{C}$ 超えていることが確認できる. これは今回用い た熱画像カメラの分解能の影響で, 系表面のみの温度だけで はなくヒー夕内の熱源を含めた平均温度の測定結果となって いることが原因といえる。 そのため, 糸温度 $T_{y}$ の結果につ いては定性的評価を行う。まずサージング未発生時に着目す ると, 系の走行が安定しているためヒータ内に施撚部からの 加撚が十分に伝播され, 見かけ糸太さ $d$ の減少と撚角度 $\theta$ の 増加によって早い段階で糸に延伸が施される，すなわち，低 い繊度の糸で加工されることから熱伝導の影響を受けやすく なり糸温度 $T_{y}$ が早く上昇したといえる。これは Fig. $9\left(T_{H}=\right.$ $300{ }^{\circ} \mathrm{C}$ ）でのサージング未発生時に拈ける, 糸の延伸の生じ ている位置が $X=400 \mathrm{~mm}$ であることと, Fig. 12 における糸

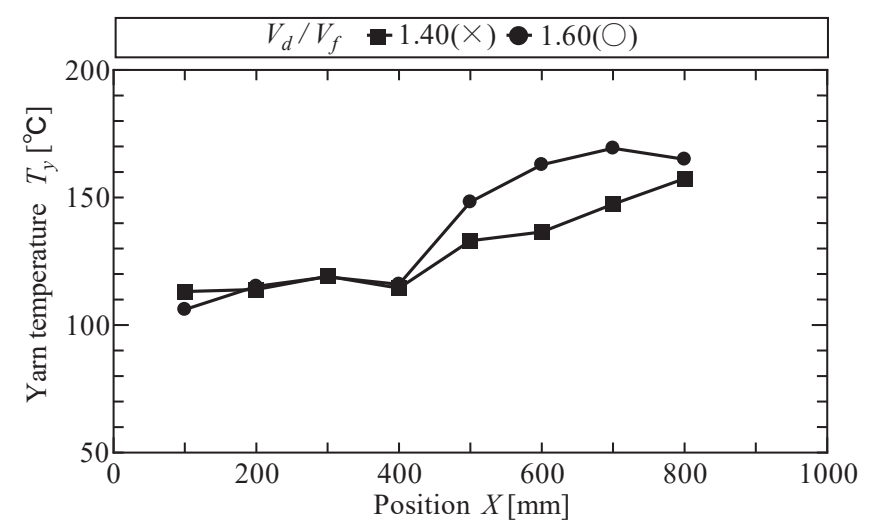

Fig. 12 Yarn temperature in heater at $T_{H}=300^{\circ} \mathrm{C}$. $(\bigcirc$ : without surging, $\quad X$ : with surging)
温度の差の生じる位置が $X=400 \mathrm{~mm}$ であることが一致して いることからも明らかである。一方, サージング発生時は糸 温度 $T_{y}$ が未発生時と比べ上昇しにくく未発生時と同じく $X=$ $400 \mathrm{~mm}$ から糸温度 $T_{y}$ の上昇が始まっているが, $X=800 \mathrm{~mm}$ まで温度差が生じており, 未発生時と同程度の糸温度になる には時間を要していた。これはサージング発生によって施撚 部からの加撚が不十分な状態であるため，時間と共に撚りが 徐々に伝播されることで延伸されて, 糸温度 $T_{y}$ も上昇してい ると考えられる。したがって，サージング発生の有無による 糸の延伸は, 糸温度 $T_{y}$ と密接に関係しているといえる.

Fig. 13 にヒー夕温度 $T_{H}=250{ }^{\circ} \mathrm{C}$, 糸送り速度 $V_{d}=300 \mathrm{~m} / \mathrm{min}$ での糸速度 $V_{y}$ と糸張力 $T$ の測定結果を示す。ここでサージン グ発生の延伸比 $V_{d} / V_{f}=1.15$ がロ. $\square$ で, 未発生の $V_{d} / V_{f}=1.35$ が○・○である. 同図のヒー夕前後 $(X=-50,1050 \mathrm{~mm})$ に拈ける加工中の糸速度 $V_{y}$ に着目すると，未発生時では発 生時より遅くなっていることがわかる。前述の通り, 加工中 の糸は螺旋方向への延伸しながら糸軸方向に収縮される。そ のため, 撚角度 $\theta$ が大きいほど糸の収縮量が増加し, この収 縮によって糸の進行方向の糸速度 $V_{y}$ は低下すると考えられ る。つまり, サージング未発生時は延伸の開始が早く, 撚角 度 $\theta$ も大きいことから加工中の糸速度 $V_{y}$ の減少が大きいと いえる。 その結果, 糸はヒータ内に長く留まろうとするため 加熱時間が増加し, 系温度 $T_{y}$ が上昇しやすくなると考えられ る. 次にヒータ入口前から冷却装置後における糸張力 $T$ に着 目すると, サージング未発生時は発生時と比べて $10 \mathrm{cN}$ 程高 い.これは螺旋方向の延伸ならびに糸軸方向の収縮が糸張力 の増加に大きく寄与していると考えられる。したがって, サー ジング未発生時はヒータ内での加工中の糸の延伸が発生時よ り早いため, 糸の収縮による糸張力 $T$ の増加によって, 糸と ディスクの接触による摩擦力も付与されやすくなる。これは 加工効率の高い安定した加撚を糸に施すことになり, 糸品質 の安定化につながると考えられる。



Fig. 13 Yarn velocity and yarn tension from feed roller to disc at $T_{H}$ $=250{ }^{\circ} \mathrm{C}$. $(\bigcirc$ : without surging, $\times$ : with surging $)$ 


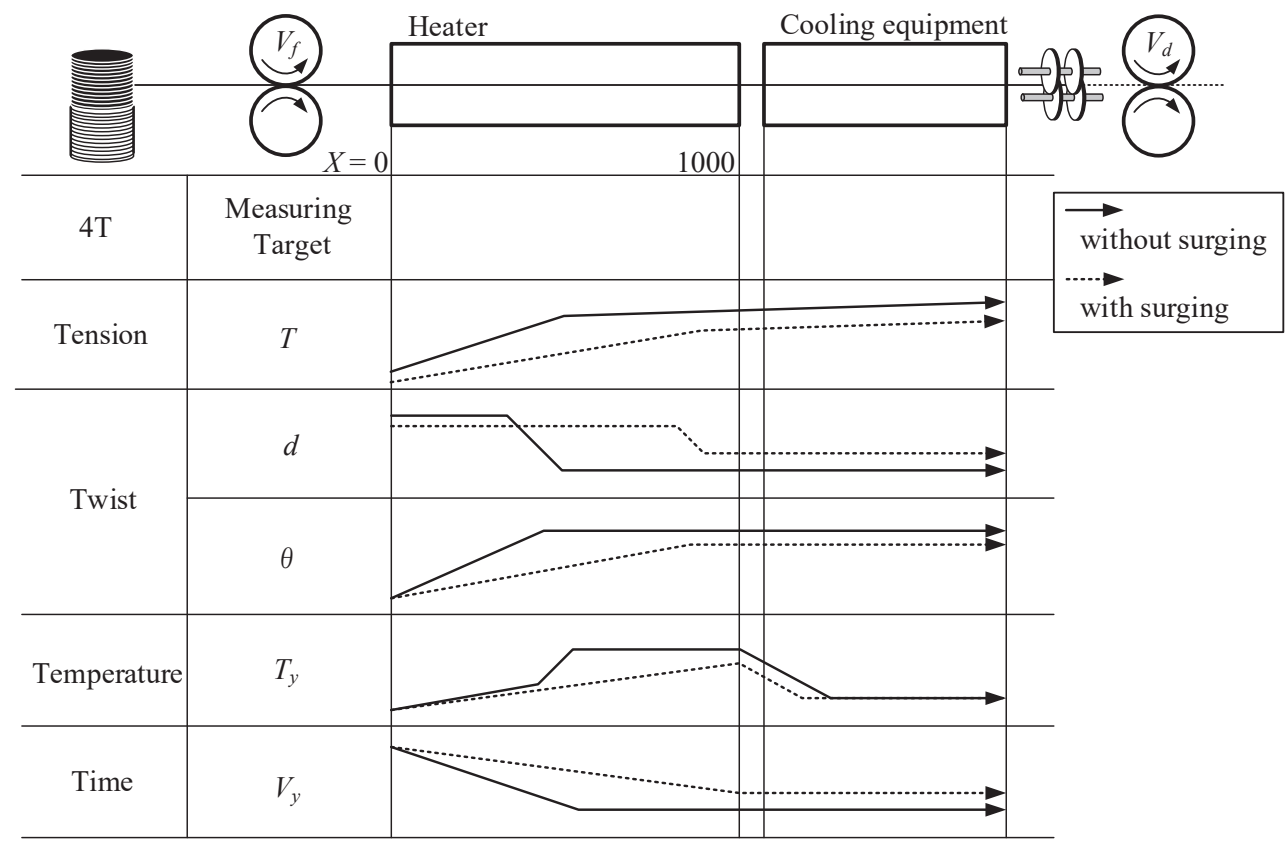

Fig. 14 Schematic chart of yarn conditions with surging and without surging in twisting area.

\section{4 サージング発生の有無による加撚領域の糸の 状態}

仮撚加工法において, 加工糸の生産に重要とされる4Tの 観点からサージングを観察した結果, 加撚領域において加工 中の糸張力および糸形状, 糸温度, 糸速度は, Fig. 14 に示す ような状態であると想定できる。サージング発生の有無に よって施撚部の糸とディスクとの接触状態は異なるため, 同 領域での糸に大きく影響を及ぼしていた。 なお，糸張力 $T$ は ヒー夕内での測定が困難であるため，糸形状の見かけ糸太さ $d$ と撚角度 $\theta$ が加撚状態となる位置まで増加傾向にあると予 想している.

しかしながら，本論文ではサージングの抑制を目的とした 検証までは至っていない. 延伸・加熱・加然といった加工条 件の観点から, 加工状態を幅広く観察し, サージング発生要 因の解明ならびに抑制方法を検討していくことが今後の課題 である。

\section{5. 結 言}

仮撚加工機に拈けるサージングと加工条件の 4T（張力・ 撚り・加熱温度・加熱時間）の相互関係を明確にすることを 目的に, サージングの未発生時と発生時とで糸張力および糸 形状, 糸温度, 糸速度の実態を把握した。 その結果, サージ ングの発生有無による加撚領域における加工中の糸のモデル を提案した。

(1) サージングが発生すると加工機全体で糸の振動が確認で き，施然部での糸もディスクに把持されておらず接触状 態は悪化していた。
（2）サージングの発生条件について，糸送り速度 $300 \mathrm{~m} / \mathrm{min}$ では延伸比 1.3 未満, 同 $500 \mathrm{~m} / \mathrm{min}$ では延伸比 1.5 未満, 同 $800 \mathrm{~m} / \mathrm{min}$ では延伸比 1.8 未満と, 糸送り速度が高速で, 延伸比が低い時に発生しやすかった。

（3）糸張力については, 加撚領域においてサージング発生よ り未発生の方が $20 \mathrm{cN}$ 程大きかった。また，サージング 未発生の場合, 施撚部での糸送り作用が発揮されて加撚 張力 $T_{4}>$ 解撚張力 $T_{5}$ となるのに対し, サージングが発 生すると糸送り作用が発揮しにくく加然張力 $T_{4}<$ 解撚 張力 $T_{5}$ となっていた.

（4）糸形状については施撚部での接触状態が大きく起因して いた。 すなわち，サージング未発生時ではヒータ内 $X \leqq$ $500 \mathrm{~mm}$ に扔いて見かけ糸太さ $0.15 \mathrm{~mm}$, 撚角度 $45 \mathrm{deg}$. と螺旋方向への延伸を伴った加然状態になっていた。一 方，サージング発生時では同 $X=500 \mathrm{~mm}$ において見か け糸太さ $0.19 \mathrm{~mm}$, 撚角度 $20 \mathrm{deg}$. と加撚が不足する状 態となっていた。

（5）ヒー夕温度はサージングの発生状況にほとんど影響を及 ぼさないが, 糸のガラス転移温度への到達時間に関わっ

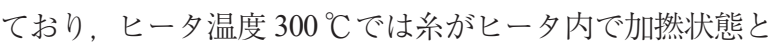

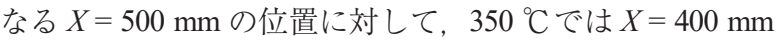
と $100 \mathrm{~mm}$ 程早くなっており，加撚のしやすさに影響を 及ぼしていた。

（6）糸温度および糸速度については, サージング未発生の場 合，加撚によって糸軸方向の収縮が生じ，糸速度が低下 することでヒータ内での加熱時間が増加するため糸温度 も増加しやすくなっていた。一方, サージングが発生す ると加撚されにくいことから糸速度は低下しにくく，加 熱時間も短くなるため糸温度が増加しにくくなっていた。 


\section{Nomenclature}

d : Apparent yarn thickness

T : Tension

$T_{1} \quad$ : Twisting tension in front of heater

$T_{2} \quad$ : Twisting tension in front of cooling equipment

$T_{3} \quad$ : Twisting tension behind cooling equipment

$T_{4} \quad$ : Twisting tension in front of disc

$T_{5} \quad$ : Untwisting tension behind disc

$T_{H} \quad$ : Heater temperature

$T_{y} \quad$ : Yarn temperature

$V_{y} \quad$ : Yarn velocity

X : Position

$\theta \quad$ : Angle of twist

\section{謝 辞}

本研究は JSPS 科研費 JP15K21587, JP18K02251 の助成を 受けたものです.

\section{References}

[1] Okuyama Y (1995) Sen'i Kikai Gakkaishi (Journal of the Textile Machinery Society of Japan), 48, P204-P210 (in Japanese). https://doi.org/10.4188/transjtmsj.48.6_P204

[2] Naito T (1997) Sen'i Kikai Gakkaishi (Journal of the Textile Machinery Society of Japan), 50, P35-P39 (in Japanese). https://doi.org/10.4188/transjtmsj.50.P35

[3] Okumura M (1998) Sen'i Gakkaishi, 54, P155-P159 (in Japanese). https://doi.org/10.2115/fiber.54.5 P155

[4] Shintaku S, Endo T, Kinari T, Tamamura R (1999) Sen'i Kikai Gakkaishi (Journal of the Textile Machinery Society of Japan) (predecessor journal of Journal of Textile Engineering), 52, T217-T224 (in Japanese). https://doi.org/10.4188/ transjtmsj.52.10_T217

[5] Shintaku S, Endo T, Kinari T, Tamamura R (2000) Sen'i Kikai Gakkaishi (Journal of Textile Machinery Society of Japan) (predecessor journal of Journal of Textile Engineering), 53, T53-T61 (in Japanese). https://doi.org/10.4188/ transjtmsj.53.3_T53

[6] Shintaku S, Endo T, Kinari T, Kobayashi S (2000) Sen'i Kikai Gakkaishi (Journal of Textile Machinery Society of Japan) (predecessor journal of Journal of Textile Engineering), 53, T155-T164 (in Japanese). https://doi.org/10.4188/ transjtmsj.53.7_T155

[7] Endo T, Shintaku S, Kinari T, Sasaya T (2001) Sen'i Kikai Gakkaishi (Journal of Textile Machinery Society of Japan) (predecessor journal of Journal of Textile Engineering), 54, T119-T125 (in Japanese). https://doi.org/10.4188/ transjtmsj.54.8_T119

[8] Endo T, Shintaku S, Kinari T (2003) Textile Research Journal, 73, 139-146. https://doi.org/10.1177/004051750307300208

[9] Endo T, Shintaku S, Kinari T (2003) Textile Research Journal, 73, 192-199. https://doi.org/10.1177/004051750307300302

[10] Kaneda N, Kinari T, Shintaku S, Shimokawa T (2007) Journal of Textile Engineering, 53, 203-210 (in Japanese). https:// doi.org/10.4188/jte.53.203

[11] Kaneda N, Kinari T, Shintaku S, Shimokawa T, Araki Y (2010) Journal of Textile Engineering, 56, 15-20 (in Japanese). https://doi.org/10.4188/jte.56.15

[12] Kaneda N, Tomohiro S, Fujita Y, Kinari T (2017) Journal of Textile Engineering, 63, 205-209 (in Japanese). https://doi. org/10.4188/jte.63.205

[13] The Textile Machinery Society of Japan (1987) "Sen-i Kogaku Part III", Chap 6, The Textile Machinery Society of Japan, Osaka

[14] Yasuzuka K, Nara H (1976) "Filament Kakougizyutu Manual" Part I, The Textile Machinery Society of Japan, Osaka

[15] Kitazawa T, Hashi E (1976) Sen'i Gakkaishi, 32, P359-P372 (in Japanese). https://doi.org/10.2115/fiber.32.10_P359

[16] Anahara M, Ikeuchi H, Fujita T, Kokubu T (1982) Sen'i Kikai Gakkaishi (Journal of Textile Machinery Society of Japan) (predecessor journal of Journal of Textile Engineering), 35, T38-T49 (in Japanese). https://doi.org/10.4188/ transjtmsj.35.3_T38

\section{文献（日本語表記）}

[13] 日本繊維機械学会 (1987) 緘維工学 (III), 第 6 章, 日本 繊維機械学会, 大阪

[14] 安塚勝三, 奈良寛久 (1976) フィラメント加工技術マニュ アル (上), 日本繊維機械学会, 大阪 